UMIBARA

Indonesian Journal of Anthropology

Volume 6 (2) Desember 2021 || eISSN 2528-1569 | pISSN 2528-2115 || http://jurnal.unpad.ac.id/umbara

DOI : $10.24198 /$ umbara.v6i2.35778

\title{
Pengetahuan Lokal Masyarakat Desa Cihanjuang, Kabupaten Sumedang tentang Bencana Longsor: Pendekatan Antropologi dan Geologi
}

\author{
Fathimah Shidqi ${ }^{1}$, Faishal Muhammad Shiddiq ${ }^{2}$, Benedictus Beryl Franklin Maspaitella ${ }_{5}^{3}$, \\ Hilfi Taufiqul Rahman , Moh. Fahrul Yahya ${ }^{4}$ \\ ${ }^{1}$ Departemen Antropologi, Fakultas Ilmu Sosial dan Ilmu Politik, Universitas Padjadjaran \\ fathimahshidqi@gmail.com \\ 2 Departemen Antropologi, Fakultas Ilmu Sosial dan Ilmu Politik, Universitas Padjadjaran \\ faishalmmm@gmail.com \\ ${ }^{3}$ Departemen Teknik Geologi, Fakultas Teknik Geologi, Universitas Padjadjaran \\ brmaspaitella@gmail.com \\ 4 Departemen Teknik Geologi, Fakultas Teknik Geologi, Universitas Padjadjaran \\ hilfitaufik@gmail.com \\ Departemen Teknik Geologi, Fakultas Teknik Geologi, Universitas Padjadjaran \\ fyahya@gmail.com
}

\begin{abstract}
This research aims at describing local knowledge about landslides among residents living in a landslide prone area; using Anthropological and Geological approach. In January 2021, a landslide occurred and killed 40 victims. This research uses qualitative and quantitative methods. Data were collected based on the Anthropology and Geology approach. Primary data were obtained through participatory observation, in-depth interviews, survey, and mapping using GIS technology. The results of this research indicate that geologically, the research location is prone to landslides. The residents have a lack of knowledge and experience about disasters, in particular landslides. Furthermore, they lack knowledge about the geological facts of the housing area. They trust the government and the developer who built the housing which they believe had considered the security of their housing.
\end{abstract}

Keywords: landslide, disaster, local knowledge, ground movement susceptibility

\begin{abstract}
Abstrak
Penelitian ini bertujuan menggambarkan pengetahuan lokal penduduk mengenai bencana dan kerentanan bencana longsor di sebuah lokasi rawan longsor; dengan menggunakan pendekatan Antropologi dan Geologi. Penelitian ini dilakukan di sebuah perumahan yang dibangun di lereng-lereng bukit rawan longsor di Desa Cihanjuang, Kecamatan Cimanggung, Kabupaten Sumedang. Pada Januari 2021, wilayah ini mengalami longsor yang menelan 40 orang korban meninggal. Metode penelitian ini menggabungkan metode kualitatif dan kuantitatif. Teknik pengumpulan data dilakukan dengan observasi berpartisipasi, wawancara mendalam, dan kuesioner. Data geologis tentang kondisi kerentanan tanah, dikumpulkan
\end{abstract}


dengan pemetaan menggunakan teknologi GIS. Hasil penelitian menunjukkan bahwa secara geologis, lokasi penelitian merupakan daerah rawan longsor. Namun masyarakat tetap membeli rumah di daerah tersebut karena kurangnya pengetahuan dan pengalaman masyarakat tentang bencana; ditambah kurangnya pengetahuan mereka mengenai fakta geogolis wilayah tersebut yang rawan longsor. Selain itu, mereka juga percaya bahwa pemerintah dan pengembang tentu telah mempertimbangkan aspek keamanan perumahan tersebut.

Kata kunci: longsor, bencana alam, pengetahuan lokal, kerentanan gerakan tanah

\section{Pendahuluan}

Pengetahuan lokal adalah proses dinamis yang selalu berubah setiap waktu melalui eksperimentasi dan adaptasi terhadap lingkungan dan perubahan sosial-ekonomi (Thrupp, 1989 dalam Susilo dan Arrozy, 2020). Pengetahuan lokal juga merujuk pada persepsi masyarakat yang merupakan hasil pengalaman empiris indrawi tentang lingkungan sekitarnya (Rosyadi, 2014). Sistem pengetahuan lokal terbentuk dari pola dan cara berpikir suatu kelompok masyarakat yang di dalamnya terdapat konsep-konsep tentang semua gejala yang dilihat, dirasakan, dialami, atau yang dipikirkan oleh masyarakat tersebut.

Indonesia adalah negara dengan keragaman sosial-budaya yang dapat dilihat dari banyaknya suku bangsa, agama, dan kepercayaan yang memiliki perangkat nilai dan normanya masing-masing. Selain itu, keberagaman juga meliputi golongan kelas sosial dengan kepentingan ekonomi-politik dan gaya hidup masing-masing. Beragamnya aspek sosial-budaya di Indonesia memengaruhi juga keragaman persepsi atas bahaya alam meliputi persepsi risiko, perilaku, dan kerentanan bencana. Di dalam konteks bencana, akumulasi empiris dan susunan pengetahuan lokal terkait bencana, menggambarkan kesiapan komunitas setempat terhadap bencana. Pengalaman dan penafsiran masyarakat atas bencana alam sudah setua upaya manusia bertahan hidup di tengah-tengah lingkungan fisik yang senantiasa berubah. Pengalaman dan penafsiran tiap kelompok di kawasan tertentu akan berbeda-beda, dan hal inilah yang kemudian dikenal dengan pengetahuan lokal (Mulyanto, 2013).

Bencana alam sering kali dipahami sebagai fenomena yang disebabkan oleh faktor alam semata. Namun, pada kenyataannya perilaku manusia juga menjadi salah satu faktor penyebabnya. Tidak semua bahaya alam terjadi sepenuhnya secara alamiah. Sebab, banyak peristiwa bahaya alam muncul akibat interaksi populasi dengan alam sekitarnya (Noveria, 2007; Mulyanto, 2013). Sebuah peristiwa alam dapat dikatakan sebagai bencana apabila terdapat korban manusia di dalamnya. Bencana alam yang awalnya merupakan fenomena alam, pada akhirnya dapat berubah menjadi fenomena sosial (Ridwan, 2010).

Salah satu contoh bencana alam adalah longsor. Longsor terjadi karena daya penahan suatu lahan hilang dan menjadi tidak stabil disebabkan erosi tanah oleh air, sehingga menyebabkan runtuhnya batuan penahan, atau adanya retakan dengan skala besar. Bencana longsor sering kali melibatkan perilaku manusia sebagai penyebabnya, misalnya pemotongan lereng bukit yang semula berfungsi untuk menahan tanah di atasnya; untuk dialihfungsikan sebagai pemukiman, penambangan, atau pembuatan sumur dan saluran air (Sumintarsih, 2008). Pada kasus ini, dapat dikatakan bahwa perilaku manusia telah memperburuk kondisi lereng yang sudah tidak stabil karena faktor alam.

Pada Januari 2021, bencana longsor terjadi di sebuah perumahan yang dibangun di lereng bukit di Desa Cihanjuang, Kecamatan Cimanggung, Kabupaten Sumedang. Longsor terjadi dua kali setelah hujan lebat turun dengan durasi yang cukup lama. Longsor pertama terjadi sekitar pukul 15.30 dan longsor susulan sekitar pukul 19.00 WIB. Tanah yang menopang pondasi beberapa rumah di ka- 
wasan tersebut longsor menerjang perumahan lain yang berada di bawahnya. Badan Penanggulangan Bencana Daerah (BPBD) Sumedang mencatat 40 korban jiwa dalam bencana itu, termasuk Danramil Cimanggung beserta petugas evakuasi dari Basarnas dan BPBD yang tertimbun oleh longsor susulan.

Bencana longsor di daerah Sumedang Selatan ini bukan yang pertama kali. Pada tahun 2014, Badan Geospasial dan Badan Pertanahan Nasional mencatat terjadinya longsor yang menyebabkan korban jiwa melanda tiga desa di Kabupaten Sumedang Selatan. Kronologi kejadian longsor hampir sama, didahului oleh hujan deras mengguyur tanah yang kondisinya labil (Mustawa dan Hindersah, 2017). Pada 2014 setelah terjadi longsor, penelitian dilakukan untuk mencegah terjadinya hal serupa, di antaranya penelitian Mustawa dan Hindersah (2017), menyatakan bahwa Sumedang Selatan merupakan daerah yang rawan longsor.

Longsor di Cimanggung menimbulkan berbagai macam persepsi dan respon masyarakat. Sebuah masjid masih berdiri kokoh di antara bangunan yang rusak oleh longsor. Hal itu membuat masyarakat percaya bahwa bertahannya masjid dari longsor merupakan mukjizat. Kepercayaan tersebut diperkuat oleh banyaknya orang yang selamat dari longsor susulan, karena mereka menyelamatkan diri ke dalam masjid. Tidak sedikit warga masyarakat yang mengaitkan longsor dengan hal-hal mistis. Beberapa orang sengaja datang ke lokasi untuk mendapatkan kekuatan mistis. Dari cerita yang beredar di masyarakat sekitar, beberapa warga mengalami kesurupan setelah longsor. Ada pula anggapan yang beredar bahwa penyebab longsor adalah karena sebagian pemilik tanah di perumahan itu berasal dari suatu suku bangsa tertentu, yang bukan warga asli setempat.

Pengetahuan lokal masyarakat di tempat longsor hanya menggambarkan aneka cara interpretasi mereka terhadap bencana. Sementara, pengetahuan lokal mereka tentang cara mencegah ataupun menjaga lingkungan tidak terlihat. Bahkan nampaknya masyarakat tidak memiliki pengetahuan kebencanaan yang me- madai yang berlandaskan pada ilmu pengetahuan. Interpretasi warga lebih banyak berlandaskan kepercayaan dan agama mereka. Padahal, menilik dari lokasi perumahan yang berada di lereng, sudah cukup menggambarkan kerentanan wilayah itu akan longsor.

Menilik pada persoalan mengenai bencana alam yang merenggut korban jiwa dan bagaimana masyarakat di wilayah tersebut menghadapinya, yang sering kali terkesan tidak ilmiah, maka gejala kebencanaan harus dikaji secara holistik, baik aspek alam maupun aspek sosial-budayanya. Kedua hal ini harus dipahami sebagai satu kesatuan (Mulyanto, 2013). Penelitian ini bertujuan untuk mengidentifikasi pengetahuan masyarakat Desa Cihanjuang, baik pengetahuan lokal maupun pengetahuan yang berlandaskan ilmu pengetahuan tentang kebencanaan. Identifikasi dan gambaran pengetahuan masyarakat di wilayah bencana, nantinya dapat menjadi bahan untuk merumuskan edukasi mengenai mitigasi bencana, dan menjadi pertimbangan, maupun acuan bagi pemerintah dan pihak-pihak lain yang berwenang dalam memberi izin penggunaan lahan untuk mencegah bencana terulang.

\section{Kajian Pustaka}

\section{Pengetahuan Lokal dan Respon Masyarakat terhadap Bencana Alam: Risiko Kebenca- naan}

Sistem pengetahuan dan pengelolaan lokal atau tradisional adalah akar dari konsep sistem pengetahuan lokal (Zamzami, 2013). Pengetahuan lokal bersumber dari kebudayaan masyarakat dan merupakan hasil dari pemaknaan filosofi hidup suatu masyarakat (Yuliaty dan Priyatna, 2014). Pengetahuan lokal mencerminkan pemikiran kreatif dan aksi dari suatu komunitas hasil dari akumulasi pengetahuan yang sudah ada dalam waktu yang sangat lama (Murdiati et al., 2016). Jadi dapat dikatakan bahwa pengetahuan lokal suatu masyarakat adalah seluruh hasil pembelajaran berdasarkan pemikiran mereka yang berasal dari pengamatan dan pengalaman empirik terhadap kejadian yang terjadi di sekitarnya, yang juga dipengaruhi oleh norma 
budaya yang berlaku di daerah tempat mereka tinggal. Oleh karena pengetahuan lokal berasal dari masyarakat setempat, maka lingkup pengetahuan tersebut hanya berlaku pada masyarakat itu saja.

Salah satu jenis pengetahuan lokal adalah pengetahuan masyarakat tentang kebencanaan dan pelestarian lingkungan. Kebudayaan bencana mencakup sistem nilai dan agama yang merangkai bahaya-bahaya alam ke dalam kehidupan dan pola pikir kolektif (Mulyanto, 2013). Dekens (2007) dalam Susilo dan Arrozy (2020) mengatakan perlunya pemahaman tentang pengetahuan lokal terkait dengan kewaspadaan bencana sebagai upaya memahami antisipasi komunitas setempat terhadap situasi yang berbahaya dari fenomena alam. Kemampuan untuk membaca lingkungan dan keberadaan sumber daya untuk mata pencaharian merupakan dasar dari antisipasi komunitas lokal ini.

Studi Schaware (1982) dalam Susilo dan Arrozy (2020) tentang folk-flood warning system di Benggala Barat India menggambarkan bagaimana masyarakat mengetahui indikasi akan terjadinya banjir. Tanda alam berupa warna awan, lokasi, intensitas dan frekuensi hujan, bunyi suara angin yang tidak lazim, perubahan kondisi aliran air, warna air, arah angin dan tumbuh-tumbuhan dipahami sebagai indikasi banjir. Selain itu perilaku tidak normal dari hewan seperti ular, tikus, burung, dan rombongan semut juga dilihat sebagai indikasi banjir.

Peran serta masyarakat sangat berpengaruh terhadap risiko suatu bencana. Baik perannya terhadap terjadinya suatu bencana, atau peran dalam meminimalisasi dampak dari bencana tersebut. Setiap kebudayaan memiliki pandangan tersendiri tentang bencana alam. Pada masyarakat yang di dalamnya terdapat beragam suku bangsa dan agama yang berbeda, mitos terkait bencana telah menjadi bagian dari kehidupan sosial mereka. Masyarakat percaya bahwa ada kekuatan gaib diluar kendali manusia yang mengatur alam ini (Yuhendri, 2021). Hal ini yang memengaruhi pandangan dan interpretasi masyarakat terhadap bencana alam.
Faktor agama maupun non-agama akan berpengaruh pada interpretasi tentang bencana. Pada masyarakat tertentu, interpretasi agama dapat menjadi lebih dominan, atau seimbang antara faktor agama dan non-agama, atau bahkan tidak melibatkan faktor agama sama sekali (Risakotta, 2009; Gazali, 2010). Interpretasi keagamaan sering kali menjadi acuan dari interpretasi masyarakat yang terkena bencana, walaupun dalam setiap masyarakat terdapat skala yang berbeda.

Masyarakat maritim di Sumatera Barat memiliki pengetahuan lokal tentang cara menjaga ekosistem laut yang menjadi penopang kehidupan mereka. Mereka menyadari eksistensi dari makhluk lain, sehingga tindakan destruktif terhadap alam jarang mereka lakukan. Mereka sadar apabila tindakan mereka tidak sesuai; menentang atau merusak alam, maka akibatnya akan mereka rasakan sendiri. Selain itu, mereka juga percaya akan kekuatan gaib yang dapat menangkal bencana alam. Misal, adanya makam ulama besar Syekh Burhanuddin dianggap dapat menolak segala bencana dan menjadi kekuatan besar untuk mengantisipasi bencana (Zamzami dan Hendrawati, 2014).

\section{Hilangnya Pengetahuan Lokal Masyarakat}

Pengetahuan lokal di masyarakat sering kali tak tertulis dan diwariskan secara turun temurun lewat aksi dan cerita dari mulut ke mulut. Pengetahuan lokal akan selalu ada apabila masyarakat terus menerapkan dan mengajarkannya pada anak-anak dan keturunannya. Namun di era globalisasi dan pesatnya perkembangan teknologi membuat pertukaran informasi dari seluruh dunia menjadi mudah. Selain informasi, ide, gagasan, dan adat kebiasaan, juga dapat terjadi pertukaran antarbudaya yang bisa membuat kebudayaan tersebut menjadi sebuah tren di belahan dunia lain, pergaulan, dan gaya hidup salah satu contohnya (Cahyadi, 2017). Di Indonesia sendiri budaya yang berasal dari luar sudah menjadi tren bagi generasi muda maupun tua. Tidak jarang nilai-nilai budaya itu secara tidak sadar telah menggantikan nilai-nilai budaya Indonesia. Adopsi nilai-nilai nonlokal dapat melunturkan dan menjauhkan masyarakat 
dari nilai-nilai lokal yang sebetulnya berharga. Apabila hal ini terjadi, maka kearifan dan pengetahuan lokal yang bersifat tak tertulis ini dapat terputus dan hilang (Abbas, 2013). Hilangnya pengetahuan lokal di masyarakat terutama tentang kebencanaan akan membuat masyarakat lebih rentan dan meningkatkan risiko mereka terhadap bencana (Cahyadi, 2017).

Pengetahuan dan kearifan lokal terbukti berharga. Kearifan lokal bernama "Smong" di Aceh, yaitu seruan untuk segera pergi ke bukit apabila terjadi gempa bumi, menyelamatkan mereka dari bahaya tsunami yang mengikuti gempa besar. Smong terbukti menyelamatkan banyak orang pada tsunami tahun 1907. Namun, pengetahuan ini telah menghilang seratus tahun kemudian. Akibatnya, banyak korban berjatuhan akibat tsunami Aceh pada 2004 yang mencapai 200.000 jiwa. Sebagian masyarakat selamat karena masih memiliki pengetahuan ini, tetapi sebagian besar menjadi korban karena ketidaktahuan mereka (Cahyadi, 2017).

\section{Manusia dan Alam Sebagai Faktor Penye- bab Longsor}

Indonesia memiliki banyak potensi bencana. Namun, dari banyaknya potensi bencana alam tersebut, longsor menjadi bencana alam yang paling sering terjadi, bahkan menempati posisi kedua setelah banjir (Puturuhu et al., 2017). Gangguan kestabilan pada tanah atau batuan penyusun lereng dan perubahan struktur muka bumi adalah proses alami yang menyebabkan terjadinya longsor (Pánek et al., 2019; Rakuasa dan Rifai, 2021). Beberapa faktor seperti kemiringan lereng, kondisi batuan dan tanah penyusun lereng, juga kondisi hidrologi memengaruhi kestabilan suatu lereng (Li et al., 2019; Rakuasa dan Rifai, 2021).

Wilayah pegunungan pada musim hujan menjadi tempat yang paling umum terjadi longsor. Rahmad et al., (2018) merujuk Sartohadi (2008) mengatakan bahwa wilayah Indonesia yang sering terjadi longsor adalah wilayah yang memiliki topografi yang curam dan curah hujannya mencapai $2000 \mathrm{~mm} /$ tahun. Curah hujan tinggi menyebabkan pergera- kan tanah atau longsor. Hal ini karena jumlah air yang turun banyak dalam waktu yang lama membuat tanah dan batuan tidak bisa mengalirkannya lagi hingga sampai pada titik jenuh (Nuraini et al., 2020).

Rahmad et al., (2018) merujuk Barus (1999) mengatakan bahwa yang menyebabkan pergerakan tanah ada dua hal, yaitu sifat fisik alami dan sifat non-alami yang bersifat dinamis. Sifat fisik alami contohnya adalah struktur geologi, bahan induk, tanah, pola drainase, bentuk lereng, dan curah hujan. Sedangkan sifat non-alami contohnya adalah penggunaan lahan dan infrastruktur. Sifat non-alami merupakan faktor yang disebabkan oleh manusia.

Kabupaten Sumedang merupakan salah satu kabupaten yang didominasi oleh morfologi perbukitan dan memiliki kondisi topografi permukaan yang beragam dari terjal hingga sangat terjal. Menurut zona fisiografi, daerah Sumedang masuk ke dalam Zona Bogor yang mempunyai ciri geologi dengan seri batuan endapan Laut Tersier yang sebagian besar terdiri atas lempung, napal, lempung tufan, batu pasir dengan endapan vulkanik (Bemmelen, 1949; Martodjodjo, 1984).

Berdasarkan Peta Geologi Indonesia, Lembar Bandung, Jawa Barat (Silitonga, 1973) dan Lembar Arjawinangun, Jawa Barat (Djuri, 1995), Kabupaten Sumedang tersusun dari jenis batuan yang terdiri atas aluvial, produk gunung api muda, dan produk gunung api tua. Pelapukan pada batuan vulkanik menghasilkan batuan lapuk dan tanah residual yang menyusun lereng-lereng di daerah studi. Tanah residual ini bersifat lepas dan rentan terhadap erosi dan longsor (Wesley, 2012).

Penyebab longsor yang bersifat non-alami adalah penggunaan lahan dan infrastruktur. Perubahan pada permukaan bumi ini menjadi salah satu penyebab terjadinya bencana alam. Fungsi lahan bagi manusia adalah untuk beraktivitas dan mempertahankan eksistensinya. Lahan tersebut dibutuhkan oleh manusia untuk tempat tinggal, tempat melakukan usaha, pemenuhan akses umum dan fasilitas lain (Pewista dan Harini, 2013). Dengan de- 
mikian, aspek sosial ekonomi ikut andil dalam perubahan penggunaan lahan dan perubahan pada permukaan bumi (Wahyuni et al., 2014).

Pengaruh perkembangan kota di dekat suatu daerah pinggiran menyebabkan perubahan penggunaan lahan pertanian menjadi nonpertanian (Eko dan Rahayu, 2012). Pemekaran wilayah yang cenderung dilakukan ke arah pedesaan membuat daerah tersebut berkembang dan menyebabkan banyak pendatang yang memutuskan untuk bermukim. Hal ini menimbulkan adanya aktivitas baru di daerah tersebut sehingga tuntutan penyediaan lahan untuk aktivitas nonpertanian pun semakin meningkat (Nuraeni et al., 2017).

Seiring dengan berkembangnya peradaban manusia dan pertumbuhan penduduk yang tinggi, kebutuhan lahan untuk aktivitas manusia juga semakin meningkat. Dapat dikatakan bahwa faktor ekonomi sangat berpengaruh terhadap alih fungsi suatu lahan. Adanya kebutuhan hidup yang harus dipenuhi mendorong para pemilik lahan untuk menjual lahan yang dimilikinya dan dialihfungsikan menjadi wilayah industri ataupun wilayah pemukiman. Penurunan kualitas lingkungan yang disebabkan oleh tidak diperhatikannya kemampuan lahan, daya dukung, dan bentuk peruntukannya akan mengganggu keseimbangan ekosistem (Pewista dan Harini, 2013).

Meningkatnya jumlah penduduk juga tidak selalu diiringi dengan kemampuan penduduk tersebut untuk mendapatkan perumahan yang layak. Di dalam kasus ini, di daerah Sumedang Selatan terdapat beberapa pabrik. Berkembangnya kawasan industri di suatu wilayah akan mendorong juga pertumbuhan penduduk di wilayah tersebut. Dengan meningkatnya jumlah penduduk, lahan untuk hunian harus semakin banyak. Tanpa mengetahui kerawanan daerah, banyak pihak yang membangun perumahan di lereng-lereng bukit di sekitar daerah Sumedang Selatan.

Bencana alam yang dikaji dari ilmu sosial akan fokus terhadap kehidupan sosial populasi dan pengaruhnya terhadap konsekuensi sosial-budaya dari bahaya alam. Teori ekologi budaya dari Julian Steward (1955) menjelas- kan bahwa lingkungan dan budaya tidak bisa dilihat secara terpisah, keduanya merupakan hasil campuran (mixed product) yang berproses lewat dialektika. Teori ini digunakan untuk menganalisis hasil kajian Antropologi dan geologi pada penelitian ini. Untuk mengaji suatu kehidupan sosial populasi, perlu adanya pemahaman atas aspek kultural bencana alam populasi tersebut. Oleh karena itu studi tentang pengetahuan masyarakat, baik pengetahuan lokal maupun pengetahuan umum tentang kebencanaan menarik untuk dikaji.

\section{Metode}

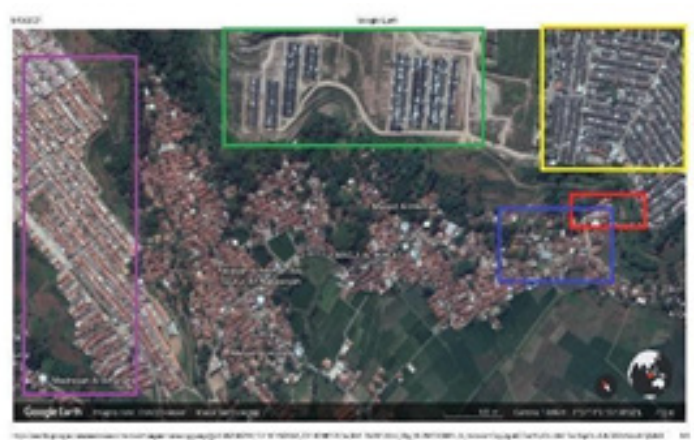

Gambar 1. Daerah Fokus Penelitian.

Sumber: Google, 2020

Lokasi penelitian ini adalah empat klaster perumahan yang terletak di Desa Cihanjuang, Kecamatan Cimanggung, Kabupaten Sumedang (lihat Gambar 1). Wilayah di kotak biru adalah Dusun Bojong Kondang, yang dihuni penduduk asli. Wilayah di kotak merah adalah lokasi terjadinya longsor, yaitu Perumahan X. Wilayah di kuning adalah Perumahan Y. Perumahan $\mathrm{Z}$ berada di kotak hijau. Sekitar 750 meter ke arah Barat X terdapat Perumahan A yang ditandai dengan kotak ungu. Perumahan ini secara administratif bukan lagi wilayah Desa Cihanjuang.

Penelitian ini menggunakan dua pendekatan yaitu antropologi dan geologi. Metode penelitian yang digunakan dalam pendekatan Antropologi adalah metode campuran (mixed method), yaitu kualitatif dan kuantitatif. Data primer diperoleh dari observasi, wawancara mendalam, dan survei kuantitatif. Sampel penelitian adalah warga di lokasi penelitian yang terdampak secara langsung maupun tidak langsung, serta warga di sekitar lokasi longsor. Wawancara mendalam berfokus pada 
respon, tanggapan, dan kegiatan masyarakat setempat terhadap longsor dan pengetahuan mereka terkait bencana longsor tersebut.

Survei kuantitatif dilakukan di empat klaster pemukiman yang menjadi daerah fokus penelitian (berada dalam wilayah dengan warna kotak berbeda). Responden dipilih dengan menggunakan metode cluster random sampling. Kriteria responden adalah telah tinggal sebelum kejadian longsor, dan berusia 15-75 tahun. Jumlah total responden survei adalah 43 orang. Pertanyaan dalam kuesioner survei mencakup tiga variabel, yaitu pengetahuan geologis tentang daerah tempat tinggal, pengetahuan kebencanaan, dan respon masyarakat terhadap longsor yang terjadi. Ketiga variabel ini digunakan untuk mendapatkan gambaran umum mengenai pengetahuan masyarakat tentang kebencanaan, terutama potensi bencana yang ada di Cimanggung.

Data sekunder diperoleh melalui studi pustaka pada referensi dari artikel dan buku yang mengaji aspek sosial-budaya pada bencana alam berupa kajian teoritis yang berkaitan dengan nilai, budaya, dan norma yang berkembang pada situasi sosial yang diteliti. Data yang dikumpulkan dengan pendekatan antropologi dianalisis dengan kerangka teori ekologi budaya dari Julian Steward (1955), yaitu bagaimana manusia, kebudayaan, dan lingkungan adalah suatu kesatuan sistem yang saling memengaruhi. Sistem ini berlaku dan saling berkaitan dengan aspek-aspek yang ada di dalam kebudayaan, seperti sistem ekonomi, sistem agama, struktur sosial, dan sistem politik.

Pendekatan Geologi dilakukan untuk memetakan zona kerentanan tanah tidak langsung. Metode ini dilakukan dengan dengan prosedur analisis tumpang tindih (overlaying) untuk mencari pengaruh faktor-faktor yang terdapat pada peta-peta parameter terhadap sebaran (distribusi) gerakan tanah, kemudian dengan analisis menggunakan SIG (Sistem Informasi Geografis) dapat ditentukan zonasi kerentanan gerakan tanahnya (lihat Tabel 1 dan Tabel 2).

\begin{tabular}{lcc}
\hline No. & Skot Tertimbang & Kategori \\
\hline 1. & $>4,3$ & $\begin{array}{l}\text { Sangat } \\
\text { Rawan }\end{array}$ \\
\hline 2. & $3,5-4,3$ & Rawan \\
\hline 3. & $2,6-3,5$ & Agak Rawan \\
\hline 4. & $1,7-2,6$ & $\begin{array}{l}\text { Sedikit } \\
\text { Rawan }\end{array}$ \\
\hline 5. & $<1,7$ & Tidak \\
& & Rawan
\end{tabular}

Tabel 1. Klasifikasi Interval Potensi Tanah Longsor. Sumber: Paimin et al., (2009)

Pengerjaan analisis dengan SIG dilakukan menggunakan perangkat lunak, untuk menghitung persentase kemiringan lereng serta mengevaluasi unit, kelas, atau tipe mana dari setiap individu peta yang penting terhadap kejadian gerakan tanah.

Analisis data mencakup proses pembentukan query (perintah pengambilan dan analisis data) dengan menggunakan fasilitas fungsi yang ada pada sistem tersebut. Peta-peta tematik hasil digitasi, dianalisis dengan menggunakan metode tumpah tindih (overlaying). Tumpang tindih dilakukan antara peta-peta parameter geologi yang digunakan seperti (kemiringan lereng, curah hujan, tata guna lahan, dan lain-lain) terhadap peta distribusi gerakan tanah. Dari hasil tumpang tindih ini dilakukan perhitungan nilai bobot (weight value) dengan menggunakan metode kuantitatif. Analisis data meliputi analisis peta geomorfologi, curah hujan serta analisis aspek keteknikan daerah penelitian yang nantinya menghasilkan sebuah peta kerentanan rawan longsor.

Pada metode analisis geomorfologi digunakan aspek-aspek pendukung yang dapat digunakan untuk mempermudah analisis tersebut, di antaranya aspek morfografi, morfometri, dan morfogenetik yang mengacu pada pendekatan yang dikembangkan oleh Van Zuidam (1985).

\section{Hasil dan Pembahasan}

Berdasarkan analisis morfografi, morfometri, dan morfogenetik daerah penelitian, daerah penelitian dibagi menjadi empat satuan geomorfologi, yaitu: 
1. Satuan Geomorfologi Perbukitan Tinggi Curam Vulkanik, terdapat di bagian tengah dan menerus ke arah Barat Laut daerah penelitian, menempati $20 \%$ dari luas keseluruhan.

2. Satuan Geomorfologi Perbukitan Tinggi Landai Vulkanik, tersebar di sebelah Timur daerah penelitian, menempati 20 $\%$ dari luas keseluruhan.

3. Satuan Perbukitan Tinggi Curam Vulkanik II, terdapat di sebelah Utara daerah penelitian, menempati $10 \%$ dari luas keseluruhan.

4. Satuan Geomorfologi Perbukitan Tinggi Datar Denudasional, terdapat di sebelah Selatan daerah penelitian, menempati $50 \%$ dari luas keseluruhan.

Ada beberapa faktor yang menyebabkan terjadinya longsor, yaitu curah hujan, morfometri lahan, geologi batuan, dan jenis tanah. Faktor ini dijadikan parameter untuk menghitung tingkat potensi tanah longsor. Adapun klasifikasi tingkat potensi longsor dibagi menjadi lima kelas, diantaranya rendah, agak rendah, sedang, agak tinggi dan tinggi (lihat Tabel 2).

\begin{tabular}{lccccc}
\hline Para- & Ren- & A- & Skor Se- & A- & Tinggi \\
meter & $\begin{array}{c}\text { dah } \\
\text { gak }\end{array}$ & $\begin{array}{c}\text { dang 3 } \\
\text { gen- }\end{array}$ & $\begin{array}{c}\text { gak } \\
\text { Ting- } \\
\end{array}$ & $\begin{array}{c}\text { Ren } \\
\text { dah 2 }\end{array}$ & \multicolumn{2}{c}{ gi 4 } \\
\hline
\end{tabular}

\begin{tabular}{llllll}
\hline Curah & & & & \\
Hujan/ & & & & \\
6 Bulan & & & & & \\
pada & & & & \\
Musim & $<20$ & $21-40$ & $41-75$ & 150 & $>150$ \\
Peng- & & & & & \\
hujan & & & & & \\
$(\mathrm{CH})$ & & & & & \\
$35 \%$ & & & & \\
\hline
\end{tabular}

\begin{tabular}{lccccc}
\hline $\begin{array}{l}\text { Morfo- } \\
\text { metri }\end{array}$ & & & & & \\
$\begin{array}{l}\text { Lahan } \\
\text { (ML) }\end{array}$ & $<14$ & $14-23$ & $23-32$ & $32-$ & \\
$25 \%$ & & & & 40 & \\
\hline Geologi & P. A- & P. Karst & P. & P. Se- & P. \\
Batuan & lu- & & Granit/ & dimen & Basal/ \\
(GB) & vial & & Lava & & Clay \\
$20 \%$ & & & & &
\end{tabular}

\begin{tabular}{lccccc}
\hline Jenis & A- & Aso- & Latosol & An- & Rego- \\
Tanah & lu- & siasi & & dosol & sol \\
$($ JT) & vial & Latosol & & & \\
$20 \%$ & & & & & \\
\hline
\end{tabular}

Tabel 2. Parameter Potensi Tanah Longsor. Sumber: Puslittanak Bogor (2004); Paimin et al., (2009); Modifikasi Yunandar (2020)

Menurut Peraturan Menteri Pekerjaan Umum No. 22/PRT/M/2007, gerakan tanah lateral dapat terjadi akibat adanya akumulasi air tanah di dasar lereng ditambah kondisi air tanah yang jenuh. Kondisi tersebut dapat disebabkan oleh curah hujan tinggi dengan rata-rata $2.500 \mathrm{~mm} /$ tahun atau $70 \mathrm{~mm} / \mathrm{jam}$ dengan intensitas hujan yang terus-menerus hingga beberapa hari berikutnya.

Berdasarkan data yang terekam di dalam situs web worldweatheronline.com, daerah Kabupaten Sumedang pada bulan Januari Juli memiliki nilai rata-rata curah hujan sebesar 495,74 $\mathrm{mm}$.

Jenis tanah yang menjadi material penyusun pada daerah penelitian yaitu Desa Cihanjuang merupakan jenis tanah $\mathrm{OH}$ dan $\mathrm{MH}$. Menurut Samtani dan Nowatzki (2006), jenis tanah ini memiliki karakteristik lempung organik dengan plastisitas sedang sampai dengan tinggi $(\mathrm{OH})$ dan lanau organik dengan plastisitas sedang sampai tinggi.

Data dari setiap parameter analisis tanah longsor terkumpul, lalu dilakukan pembobotan berdasarkan Tabel 2 untuk mengetahui tingkat kerentanan tanah longsor pada masing-masing satuan geomorfologi. Setelah itu, dilakukan klasifikasi untuk mengetahui satuan geomorfologi mana yang paling rawan longsor, dengan menggunakan perhitungan:

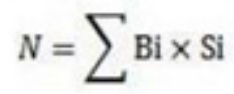

Risk Level $=\mathrm{Bi} 1+\mathrm{Bi} 2+\mathrm{Bi} 3+\ldots+\mathrm{Bi} \mathrm{n}$

Keterangan:

$\mathrm{N}=$ Total nilai pembobotan

$\mathrm{Bi}=$ Bobot setiap kriteria 
$\mathrm{Si}=$ Skor setiap kriteria

$\mathrm{n}=$ Jumlah kelas parameter

Dari empat satuan geomorfologi daerah penelitian, pembobotan menunjukkan hasil sebagai berikut (lihat Tabel 3):

\begin{tabular}{llll}
\hline Wila- & & \\
yah Sa- \\
tuan & & & \\
Geo- & Parameter & Jum- & Ke- \\
mor- & & lah & las \\
fologi & & \\
\hline
\end{tabular}

\begin{tabular}{|c|c|c|c|c|c|c|}
\hline & $\mathrm{OH}$ & ML & GB & JT & & \\
\hline $\begin{array}{l}\text { Satuan } \\
\text { Perbukitan } \\
\text { Tinggi } \\
\text { Curam } \\
\text { Vulkanik }\end{array}$ & 1.75 & 0.75 & 0.8 & 0.6 & 3.9 & $\begin{array}{l}\text { Ra- } \\
\text { wan }\end{array}$ \\
\hline $\begin{array}{l}\text { Satuan } \\
\text { Perbukitan } \\
\text { Tinggi } \\
\text { Datar } \\
\text { Denuda- } \\
\text { sional }\end{array}$ & 1.75 & 0.25 & 0.2 & 0.2 & 2.4 & $\begin{array}{l}\text { Se- } \\
\text { di- } \\
\text { kit } \\
\text { Ra- } \\
\text { wan }\end{array}$ \\
\hline $\begin{array}{l}\text { Satuan } \\
\text { Perbukitan } \\
\text { Tinggi } \\
\text { Curam } \\
\text { Vulkanik }\end{array}$ & 1.75 & 0.75 & 0.6 & 0.6 & 3.7 & $\begin{array}{l}\text { Ra- } \\
\text { wan }\end{array}$ \\
\hline $\begin{array}{l}\text { Satuan } \\
\text { Perbukitan } \\
\text { Landai } \\
\text { Vulkanik }\end{array}$ & 1.75 & 0.25 & 0.8 & 0.6 & 3.4 & $\begin{array}{l}\text { A- } \\
\text { gak } \\
\text { Ra- } \\
\text { wan }\end{array}$ \\
\hline
\end{tabular}

Tabel 3. Pembobotan dan Pengkelasan Potensi Tanah Longsor.

Hasil pembobotan dan pengkelasan potensi tanah longsor ini digunakan untuk membuat peta kerentanan rawan longsor daerah $\mathrm{Ci}$ manggung (lihat Gambar 4).

Lokasi Perumahan X yang longsor di Desa Cihanjuang berada di pinggir tebing yang curam. Jalan menuju lokasi, yaitu Jalan Cipareuag lebarnya kurang lebih 3 meter. Jalanan rusak berbatu, ditambah banyaknya tanah basah yang berasal dari kebun-kebun warga di pinggirnya menjadi salah satu faktor sulitnya akses menuju lokasi perumahan ini. Mayoritas warga sekitar menggunakan motor ataupun berjalan kaki untuk mobilitas sehari-hari.

Secara garis besar, penduduk Desa Cihanjuang terbagi menjadi dua, yaitu penduduk asli yang sudah lama bermukim di sana, dan penduduk baru. Penduduk perumahan dapat dikatakan sebagai salah satu penduduk baru, karena izin perumahan ini baru tercatat pada tahun 2017.

Setelah longsor, Jalan Cipareuag menjadi kotor dipenuhi oleh tanah-tanah basah bekas longsoran. Bangunan masjid dan satu rumah di depannya menjadi bangunan yang selamat dari terjangan longsor. Saat longsor susulan, warga sekitar dan aparat yang sedang mengevakuasi korban menyelamatkan diri ke dalam masjid tersebut. Tanah yang menimbun rumah-rumah di Perumahan X setelah enam bulan sudah ditumbuhi oleh rumput-rumput liar (lihat Gambar 2 dan Gambar 3). Kebun-kebun milik warga yang berada tepat di pinggir lokasi kejadian tidak mengalami kerusakan, sehingga warga yang mata pencahariannya sebagai petani masih melanjutkan aktivitasnya seperti biasa. Penduduk asli pemilik dari rumah-rumah yang berjarak sekitar 5 sampai 10 meter dari kaki longsoran, terlihat sudah kembali dan melanjutkan aktivitas sehari-hari.

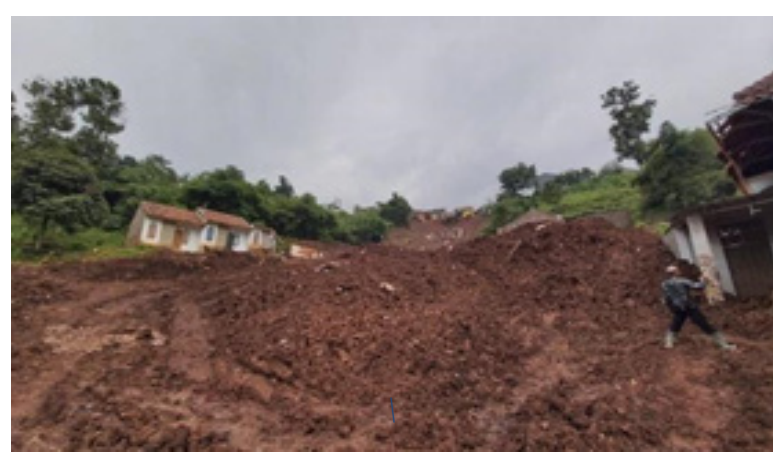

Gambar 2. Lokasi Longsor Bulan Januari 2021. Sumber: Dokumentasi Peneliti

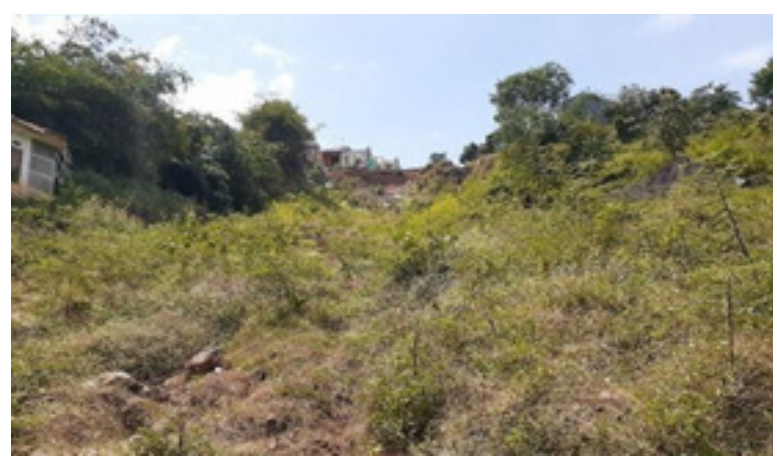

Gambar 3. Lokasi Longsor Bulan Agustus 2021. Sumber: Dokumentasi Peneliti

Kerentanan Wilayah terhadap Bencana 


\section{dan Preferensi Masyarakat dalam Memi- lih Lokasi Tempat Tinggal}

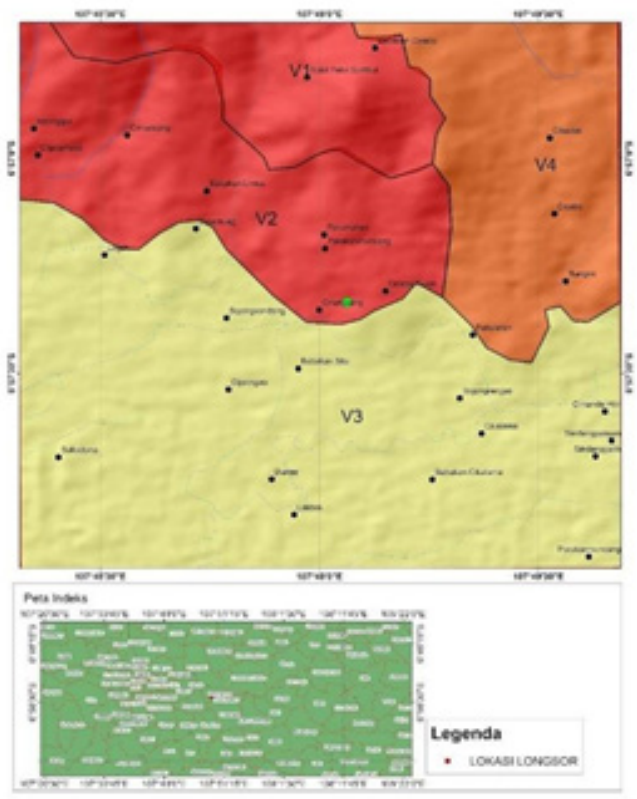

Gambar 4. Peta Kerentanan Rawan Longsor Daerah Penelitian.

Sumber: Dokumentasi Peneliti

Titik hijau pada peta pada Gambar 4 adalah lokasi kejadian longsor. Titik tersebut berada pada zona merah V2 yang apabila dilihat pada Tabel 4 adalah daerah perbukitan tinggi yang curam dan sangat rawan terkena longsor. Empat klaster pemukiman yang menjadi daerah fokus penelitian juga semua berada di zona merah V2. Perumahan lain di sekitarnya yakni Perumahan Y termasuk ke dalam perumahan besar yang ada di Cimanggung.

Tanpa peta kerentanan rawan longsor sekalipun, kemiringan lereng dapat dilihat dan dirasakan ketika menyusuri jalan di perumahan-perumahan tersebut. Contohnya pada X, kemiringan jalan dapat mencapai 30-40 derajat. Semakin ke atas, kemiringan pun semakin bertambah bisa mencapai 50 derajat. Hal tersebut dapat pula ditemukan di Perumahan Y.

\begin{tabular}{lll}
\hline $\begin{array}{l}\text { Wilayah Satuan } \\
\text { Geomorfologi }\end{array}$ & Kelas & Simbol \\
\hline $\begin{array}{l}\text { Satuan Perbukitan } \\
\text { Tinggi Curam }\end{array}$ & Rawan & V1 \\
Vulkanik & & \\
\hline $\begin{array}{l}\text { Satuan Perbukitan } \\
\text { Tinggi Datar } \\
\text { Denudasional }\end{array}$ & Sedikit & V2 \\
\hline $\begin{array}{l}\text { Satuan Perbukitan } \\
\text { Tinggi Curam }\end{array}$ & Rawan & V3 \\
Vulkanik & & \\
\hline $\begin{array}{l}\text { Satuan Perbukitan } \\
\text { Landai Vulkanik }\end{array}$ & Agak & V4 \\
\hline
\end{tabular}

Tabel 4. Klasifikasi Kerentanan Gerakan Tanah di Cimanggung. Sumber: Dokumentasi Peneliti

\section{Pengetahuan Penduduk tentang} Potensi Bencana

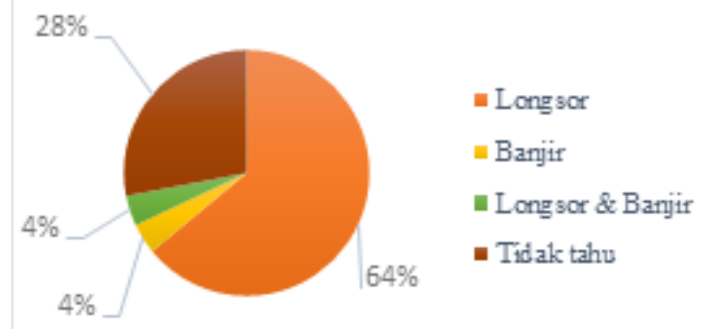

Gambar 5. Diagram Pengetahuan Penduduk tentang Potensi Bencana. Sumber: Dokumentasi Peneliti

Dapat dilihat pada Gambar 5, pengetahuan penduduk setempat tentang potensi bencana longsor di daerah tempat tinggalnya. Mereka dapat melihat sendiri bahwa perumahan-perumahan yang ada di daerah tersebut dibangun di lereng-lereng bukit yang curam. Ada ketakutan tersendiri saat melihat rumah-rumah berjajar mengikuti kontur bukit yang semakin lama kemiringannya semakin curam. Akan tetapi kemudian mereka tidak memikirkan lagi curamnya jalan perumahan, karena tidak menghalangi mereka menjalani aktivitas sehari-hari. 


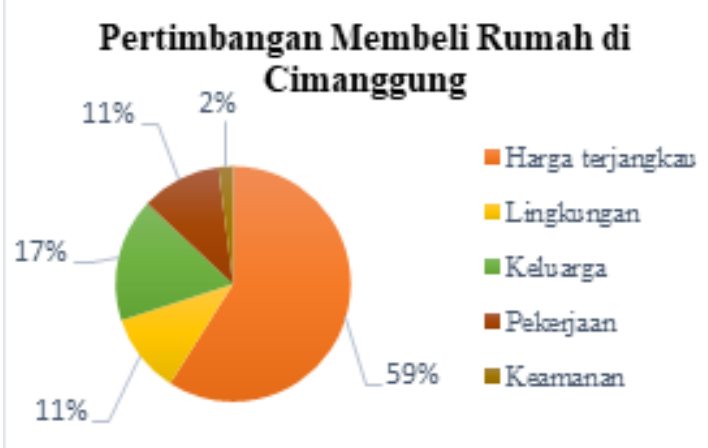

Gambar 6. Diagram Pertimbangan Membeli Rumah di Cimanggung.

Sumber: Dokumentasi Peneliti

Berdasarkan Gambar 6, nampaknya potensi bencana tidak menjadi faktor utama yang dipertimbangkan untuk membeli rumah tinggal di Cimanggung. Mayoritas penduduk yang membeli rumah di Cimanggung adalah pendatang dan berasal dari golongan ekonomi menengah ke bawah. Ada yang berasal dari Kota Bandung, dan ada juga yang berasal dari Jawa Tengah. Karena harga tanah di perkotaan semakin tinggi, banyak orang yang memilih untuk menyewa daripada membeli rumah. Namun, biaya sewa yang harus dibayar setiap bulannya juga tinggi.

Perumahan di Desa Cimanggung terdiri dari rumah subsidi dengan pembayaran KPR yang dibangun oleh pemerintah. Perumahan subsidi menawarkan rumah dengan uang muka setara dengan biaya kontrakan satu bulan. Orang yang penghasilannya tidak seberapa tetapi ingin segera memiliki rumah pastinya akan memilih untuk membeli rumah di salah satu perumahan ini. Harga rumah yang terjangkau menjadi faktor pertimbangan utama mereka memilih untuk tinggal di Cimanggung sekalipun itu merupakan daerah yang rawan longsor. Baru kemudian dilanjut oleh preferensi lainnya seperti lingkungan hunian yang nyaman, sesuai dengan kebutuhan, dan sarana prasarana yang memadai adalah beberapa faktor pertimbangan dalam pemilihan lokasi tempat tinggal.

Banyak penduduk Cimanggung yang menge- sampingkan potensi terjadinya bencana karena faktor kepercayaan terhadap pemerintah dan pengembang. Mereka pikir, pemerintah yang menyetujui dan mengeluarkan izin pembangunan perumahan KPR tentunya telah melakukan riset terhadap daerah pembangunan yang menjamin keamanan perumahan yang dibangun.

\section{Pengetahuan Lokal tentang Bencana Longsor}

Sebelum keluarnya pernyataan resmi dari pemerintah tentang penyebab longsor, orang Cimanggung telah menyimpulkan berbagai hal tentang penyebab terjadinya longsor tersebut berdasarkan pengalaman indrawi mereka yang kemudian menghasilkan pengetahuan lokal komunitas.

Kejadian longsor yang terjadi menimbulkan banyak persepsi di masyarakat. Ada persepsi yang relatif tepat, dan persepsi yang tidak tepat. Persepsi yang tepat, mirip dengan penjelasan geologi tentang longsor. Sedangkan persepsi yang tidak tepat lebih banyak dilandasi oleh asumsi-asumsi yang sukar dibuktikan

\section{Persepsi penduduk Cimanggung yang rela- tif tepat tentang longsor}

Saat Perumahan X mulai dibangun pada tahun 1996 dengan tanah urugan, tebing-tebing di sekitar perkebunan pun mulai dicor. Menurut warga, tanah urugan sangat mudah menyerap air. Pembangunan rumah tidak diiringi dengan pembangunan drainase yang sesuai, sehingga air dari permukaan masuk dan diserap oleh tanah melalui retakan-retakan, bukan melalui saluran dan mengalir ke tempat yang seharusnya. Beberapa penduduk Y sempat menanam pohon di lereng-lereng bukit untuk mencegah longsor, tetapi pohon-pohon tersebut ditebang saat pembangunan jalan akses menuju Perumahan Z. Warga Bojong Kondang yang sudah tinggal lebih dulu di sana sebelum adanya pembangunan merasa dirugikan dan tidak mendapatkan ganti rugi sama sekali.

Masyarakat menganggap bahwa pembangunan tiga perumahan di sekitar lokasi kejadian 
menjadi salah satu faktor penyebab terjadinya longsor. Tanah menjadi rapuh karena getaran-getaran yang disebabkan oleh banyaknya kendaraan berat yang berlalu lalang saat pembangunan Y. Sekitar 20 tahun yang lalu, Desa Cihanjuang khususnya daerah yang dipakai untuk Perumahan $\mathrm{X}$ adalah kebun teh dan lahan garapan masyarakat yang bekerja sebagai petani. Daerah sekitar Bojong Kondang masih berbentuk hutan dan menjadi tempat untuk membuat batu bata.

Persepsi masyarakat tentang penyebab longsor ini dapat dikatakan tepat karena berdasarkan hasil penelitian lapangan geologi, kestabilan lereng di Kecamatan Cimanggung, khususnya Desa Cihanjuang dengan kondisi tanpa beban sudah termasuk ke dalam kelas lereng yang labil. Hal ini dihitung menggunakan dua metode yaitu Bishop dan Janbu, yang menghasilkan angka 0,955 dan 0,933. Kedua angka ini menunjukan ketidakstabilan lereng tanpa adanya variabel gangguan. Apabila lereng sudah termasuk ke dalam kelas labil bahkan saat tidak ada beban apapun, maka dengan dibangunnya perumahan kestabilan lereng akan semakin berkurang dan pada akhirnya longsor pun tidak bisa dihindari.

Menurut salah satu warga, longsor yang turun bergelombang seperti ombak. Hal tersebut dikarenakan tanah dibawa oleh air yang ada dibawahnya. Air yang masuk terus menerus dan terbendung lama di dalam tanah sama seperti balon yang diisi air, pada akhirnya akan meledak, kata orang tua sekitar menanggapi kejadian longsor tersebut. Analogi penduduk Cimanggung terhadap penyebab longsor yaitu air di dalam tanah juga relatif tepat karena secara geologi, air dari permukaan yang masuk ke dalam tanah melalui retakan-retakan yang ditimbulkan oleh pembangunan perumahan akan tertampung. Kapasitas dan kekuatan tanah untuk menampung akan berkurang apabila air secara terus-menerus dan dalam jangka waktu yang panjang masuk ke dalam tanah. Apabila hal itu terjadi, maka tanah akan mengeluarkan air tersebut dalam bentuk longsor. Berbeda dengan pengetahuan lokal yang hanya berlaku pada suatu lingkup masyarakat, pengetahuan ilmiah ini mungkin didapatkan dari luar masyarakat seperti sekolah, media, dan lainnya; sehingga lingkup keberlakuannya pun luas, dalam kasus ini bukan hanya berlaku di Cimanggung.

\section{Pseudoscience: persepsi berdasarkan penge- tahuan ilmiah-semu}

Sebagian persepsi tentang longsor penduduk Cimanggung sudah tepat dengan penemuan geologi tentang kondisi lapangan di sana. Namun ada beberapa persepsi yang mereka percayai bahwa persepsi tersebut juga berdasarkan pada pengetahuan geologi. Akan tetapi, pengetahuan tersebut tidak sepenuhnya benar sehingga dikategorikan sebagai pseudoscience atau pengetahuan ilmiah yang semu.

Saat longsor pertama, terdengar letusan dari bagian bawah yang lalu membuat bagian atas ikut tergusur. Baju dan tubuh dari orang-orang yang selamat dari longsoran, tertutupi oleh debu. Masyarakat menganggap debu-debu dari tanah tersebut adalah abu vulkanik, sehingga beredar informasi bahwa terdapat aktivitas vulkanik di sekitar lokasi longsor.

Adanya aktivitas vulkanik ini sulit untuk dibuktikan secara geologis. Walaupun benar bahwa tanah penyusun Desa Cihanjuang yang terkena longsor adalah hasil dari gunung api yang sudah mengendap bertahun-tahun lamanya, akan tetapi daerah Cimanggung sendiri jauh dari lokasi gunung api aktif. Mengenai suara letusan sebelum longsor yang didengar oleh orang-orang, ada kemungkinan suara tersebut bukanlah suara letusan dari aktivitas vulkanik melainkan gemuruh air yang keluar dari tanah dan menyebabkan longsor.

\section{Simpulan}

Kecamatan Cimanggung berada di lereng-lereng bukit yang secara geologis tergolong sebagai kawasan dengan kestabilan yang labil bahkan tanpa beban di atasnya. Perumahan-pe- 
rumahan besar yang dibangun di Cimanggung dalam kurun waktu 30 tahun terakhir membuat kestabilan lereng semakin labil, sehingga longsor pun sangat mungkin terjadi. Menjadi sebuah pertanyaan besar mengapa pemerintah dapat mengeluarkan izin untuk pembangunan perumahan besar di daerah yang rawan longsor.

Penduduk di perumahan mengetahui bahwa daerah Cimanggung rawan longsor. Tetapi karena kondisi ekonomi, mereka tetap memilih untuk membeli rumah di sana karena harga beli yang ditawarkan murah. Penduduk percaya kepada pemerintah dan pengembang bahwa mereka sebelumnya sudah melakukan riset terlebih dahulu tentang wilayah yang akan dibangun, sehingga aspek potensi bencana menjadi faktor pertimbangan paling akhir dalam mengambil keputusan untuk membeli rumah di Cimanggung.

Pengetahuan lokal warga Cimanggung mengenai bencana kurang memadai dan tidak terlalu terlihat. Hal ini karena mayoritas penduduknya adalah pendatang dari berbagai daerah yang memiliki perbedaan dalam cara berpikir. Penduduk Cimanggung juga sebelumnya tidak pernah menghadapi bencana alam longsor, sehingga akumulasi pengalaman empirik dalam menghadapi bencana tidak memadai dan hampir tidak ada untuk mereka aplikasikan saat menghadapi bencana longsor yang terjadi. Kurangnya pengalaman dan edukasi kebencanaan, memunculkan persepsi-persepsi yang kurang tepat tentang bencana longsor, terutama terkait dengan kepercayaan dalam agama mereka.

\section{Ucapan Terima Kasih}

Terima kasih untuk Kementerian Riset, Teknologi, dan Pendidikan Tinggi yang sudah mendanai penelitian ini sehingga penelitian dapat dilakukan sesuai dengan apa yang sudah direncanakan. Terima kasih kepada masyarakat Kecamatan Cimanggung, terutama masyarakat Desa Cihanjuang yang sudah membantu dan mendukung penelitian kami dengan memberikan data, informasi, dan cerita berkaitan dengan longsor yang terjadi. Terima kasih juga kepada
Dr. Dra. Selly Riawanti, M. A. (Fakultas Ilmu Sosial dan Ilmu Politik, Universitas Padjadjaran), dan Dr. Ir. Dicky Muslim, M. Sc. (Fakultas Teknik Geologi, Universitas Padjadjaran) selaku dosen pembimbing yang telah membantu dalam penelitian juga penyusunan artikel ini.

\section{Daftar Pustaka}

Abbas, I. (2013). Pappaseng: Kearifan Lokal Manusia Bugis Yang Terlupakan. Sosiohumaniora, 15(3), 272-283. https://doi.org/10.24198/ sosiohumaniora.v15i3.5752

Barus, B. (1999). Landslide Hazard Mapping based on GIS Univariate Statistical Classification: Case Study of Ciawi-Puncak-Pacet Regions, West Java. Jurnal Ilmu Tanah dan Lingkungan, 2(1), 7-16. https://doi.org/10.29244/ jitl.2.1.7-16

Bemmelen, R. W. V. (1949). The Geology of Indonesia: Economic Geology. U.S. Government Printing Office.

Cahyadi, A. (2013). Krisis Identitas, Putusnya Estafet Kearifan Lokal dan Peningkatan Risiko Bencana. Di dalam Marfai dan Widyastuti (Eds.). Pengelolaan Lingkungan Zamrud Khatulistiwa (hal. 114-118). Yogyakarta: Pintal. https://doi.org/10.31227/osf.io/u536q

Dekens, J. (2007). Local Knowledge for Disaster Preparedness: A Literature Review. International Centre for Integrated Mountain Development (ICIMOD).

Djuri. (1995). Peta Geologi Lembar Arjawinangun, Jawa. Pusat Penelitian dan Pengembangan Geologi.

Eko, T., dan Rahayu, S. (2012). Perubahan Penggunaan Lahan dan Kesesuaiannya terhadap RDTR di Wilayah Peri-Urban Studi Kasus: Kecamatan Mlati. Jurnal Pembangunan Wilayah \& Kota, 8(4), 330-340. https://doi. org/10.14710/pwk.v8i4.6487

Gazali, H. (2010). Interpretasi Pesantren atas Banjir: Studi atas Pondok Pesantren Darun Najah Situbondo. Tesis. Yogyakarta: UGM.

Kasih, N. A., dan Rahmawati, D. (2019). Perspektif Kebijakan Lokal Terkait Penyediaan Permukiman Bagi Masyarakat Berpenghasilan Rendah di Kota Mataram. Seminar Nasional Pembangunan Wilayah Dan Kota Berkelanjutan, 1(1), 237-246. https://doi.org/10.25105/ pwkb.v1i1.5282

Li, C., Fu, Z., Wang, Y., Tang, H., Yan, J., Gong, W., Yao, W., dan Criss, R. E. (2019). Susceptibility of Reservoir-induced Landslides and 
Strategies for Increasing the Slope Stability in The Three Gorges Reservoir Area: Zigui Basin as an Example. Engineering Geology, 261. 105279. https://doi.org/10.1016/j.enggeo.2019.105279

Martodjodjo, S. (1984). Evolusi Cekungan Bogor Jawa Barat. Tesis. Bandung: ITB.

Mulyanto, D. (2013). Bencana Alam: Suatu Tinjauan Antropologis dengan Kekhususan Kasus-kasus di Indonesia. Jurnal Ilmiah Etnografi Papua, 57-75.

Murdiati, E. (2016). Pengetahuan Ekologi Lokal. Wardah, 16(2), 155-165.

Mustawa, Y., dan Hindersah, H. (2017). Kajian Resiko Bencana Longsor di Desa Citengah - Kecamatan Sumedang Selatan. Prosiding Perencanaan Wilayah dan Kota, 3(1), 159165.

Noveria, M. (2007). Bencana Alam dari Sisi Kependudukan: Penyebab dan Dampaknya. Masyarakat Indonesia, 33(2), 125-130.

Nuraeni, R., Sitorus, S. R. P., dan Panuju, D. R. (2017). Analisis Perubahan Penggunaan Lahan dan Arahan Penggunaan Lahan Wilayah Di Kabupaten Bandung. Buletin Tanah dan Lahan, 1(1), 79-85.

Nuraini, Diana, L., dan Falisa. (2020). Potensi Tanah Longsor Dilihat dari Karakteristik Geologi serta Pengaruh dari Intensitas Curah Hujan di Daerah Jampang Kulon, Sukabumi. AVOER, 12, 748-751.

Pánek, T., Břežný, M., Kapustová, V., Lenart, J., dan Chalupa, V. (2019). Large Landslides and Deep-Seated Gravitational Slope Deformations in The Czech Flysch Carpathians: New LiDAR-Based Inventory. Geomorphology, 346, 106852. https://doi.org/10.1016/j.geo morph.2019.106852

Pewista, I., dan Harini, R. (2013). Faktor dan Pengaruh Alih Fungsi Lahan Pertanian terhadap Kondisi Sosial Ekonomi Penduduk di Kabupaten Bantul. Kasus Daerah Perkotaan, Pinggiran, Dan Pedesaan Tahun 2001-2010. Jurnal Bumi Indonesia, 2(2), 96-103.

Puturuhu, F., Danoedoro, P., Sartohadi, J., dan Srihadmoko, D. (2017). The Development of Interpretataion Method for Remote Sensing Imagery In Determining The Candidate of Landslide In Leitimur Paninsula, Ambon Island. Jurnal Ilmu Lingkungan, 15(1), 20-34. https://doi.org/10.14710/jil.15.1.20-34

Rahmad, R., Suib, S., dan Nurman, A. (2018). Aplikasi SIG Untuk Pemetaan Tingkat Ancaman Longsor Di Kecamatan Sibolangit, Kabupaten Deli Serdang, Sumatera Utara. Majalah
Geografi Indonesia, 32(1), 1-13. https://doi. org/10.22146/mgi.31882

Rakuasa, H., dan Rifai, A. (2021). Pemetaan Kerentanan Bencana Tanah Longsor Berbasis Sistem Informasi Geografis Di Kota Ambon. Seminar Nasional Geomatika: Informasi Geospasial untuk Inovasi Percepatan Pembangunan Berkelanjutan. https://doi. org/10.24895/sng.2020.0-0.1148

Ridwan, I. R. (2010). Menyikapi Bencana Sebagai Fenomena Sosial Terintegrasi. Jurnal Geografi Gea, 10(1). https://doi.org/10.17509/gea. v10i1.1663

Risakotta, B. A. (2009). Is There a Meaning in Natural Disaster? Constructions of Culture, Religion and Science. Exchange: Journal of Missiological and Ecumenical Research, 38(3), 226-243.

Rosyadi, R. (2014). Sistem Pengetahuan Lokal Masyarakat Cidaun - Cianjur Selatan Sebagai Wujud Adaptasi Budaya. Patanjala: Jurnal Penelitian Sejarah Dan Budaya, 6(3), 431446. https://doi.org/10.30959/ptj.v6i3.173

Samtani, N. C., dan Nowatzki, E. A. (2006). Unified Soil Classification System (ASTM D 2487). Soils and Foundations, National Highway Institute, Reference Manual, 1, 3-25.

Sartohadi, J. (2008). The Landslide Distribution in Loano Sub-District, Central Java Province, Indonesia. Forum Geografi, 22(2), 129-144.

Schware, R. (1982). Official and Folk Flood Warning Systems: An Assessment. Environmental Management, 6(3), 209-216. https://doi. org/10.1007/BF01866884

Silitonga, P. H. (1973). Peta Geologi Lembar Bandung, Jawa, Skala 1:100.000. Direktorat Geologi.

Spradley, J. P. (1979). The Ethnographic Interview. New York: Holt, Rinehart, and Winston.

Subiyanto, I. (2016). Melacak Mitos Merapi: Peka Membaca Bencana, Kritis Terhadap Kearifan Lokal. Yogyakarta: Jogja Bangkit Publisher.

Sumintarsih. (2008). Strategi Bertahan Hidup Penduduk di Daerah Rawan Ekologi. Jantra, 3(5), 313-389.

Susilo, R. K. D., dan Arrozy, A. (2020). Pengetahuan Lokal sebagai Reaksi Komunitas dalam Manajemen Bencana (Studi Etnografi Warga Brau, Batu, Indonesia) Local Knowledge as Community Reaction in Management of Disaster. Sodality: Jurnal Sosiologi Pedesaan, 8(3), 1-13.

Van Zuidam, R. A. (1985). Aeral Photo-Interpretation in Terrain Analysis and Geomorphologic 
Mapping. Netherlands: Smits Publishers.

Wahyuni, S., Guchi, H., dan Hidayat, B. (2014).

Analisis Perubahan Penggunaan Lahan dan Penutupan Lahan Tahun 2003 dan 2013 di Kabupaten Dairi. Jurnal Agroekoteknologi Universitas Sumatera Utara, 2(4), 13101315. https://doi.org/10.32734/jaet.v2i4.8420

Wesley, L. (2012). Mekanika Tanah untuk Tanah Resapan dan Residu. Yogyakarta: ANDI Yogyakarta.

Yuhendri, P. (2021). Tradisi Doa Padang di Kabupaten Kuantan Singingi: Kajian Antropologis. Nusantara: Journal for Southeast Asian Islamic Studies, 16(2), 90-98. https://doi. org/10.24014/nusantara.v16i2.13635

Yuliaty, C., \& Priyatna, F. N. (2014). Lubuk Larangan: Dinamika Pengetahuan Lokal Masyarakat Dalam Pengelolaan Sumber Daya Perikanan Perairan Sungai di Kabupaten Lima Puluh Kota. Jurnal Sosial Ekonomi Kelautan Dan Perikanan, 9(1), 115-125. https:// doi.org/10.15578/jsekp.v9i1.1189

Zamzami, L. (2013). Sekerei Mentawai: Keseharian dan Tradisi Pengetahuan Lokal yang Digerus oleh Zaman. Antropologi Indonesia, 34(1), 1-17.

Zamzami, L., \& Hendrawati. (2014). Kearifan Budaya Lokal Masyarakat Maritim untuk Upaya Mitigasi Bencana Di Sumatera Barat. Jurnal Antropologi: Isu-Isu Sosial Budaya, 16(1), 37-48. https://doi.org/10.25077/jantro. v16i1.18 